\title{
My Journey from Islamist to Free Thinker
}

\section{Mubarak Bala*}

*Correspondence: [Twitter@mubarakbala]

Innii umirtu an uqaatilan-Nasa, hatta yash-hadu an Lailaha illallah...ilaa akhir...

I have been commanded (by Allah) to wage war on all mankind, until they testify that there's no god but Allah... If they do then they're safe from me. They and their families and belongings are safe...

\section{- Hadith of the Prophet of Islam.}

The above words are not the words of Shekau, al-Baghdadi or Bin Laden but a hadith (sayings of Prophet Mohammed) of significant value and source. Vital, if you wish to understand the mind of a jihadist.

Naturally, anyone born in a specific region of the world grows to

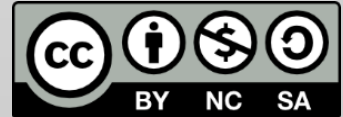

(c) Copyright: The Authors. This article is issued under the terms of the Creative Commons Attribution NonCommercial Share Alike License, which permits use and redistribution of the work provided that the original author and source are credited, the work is not used for commercial purposes and that any derivative works are made available under the same license terms. assimilate that society's culture, behaviour, way of thought and religion. So what changed me? The answer is simple. I asked the right questions. I learned, reasoned and researched and took the decision to do what is right: to be what gave me peace of mind and what satisfied my conscience.

From a life of a pseudo-Islamist, I weaned myself to be liberal, secular, humanist, agnostic and, finally, an atheist, all without ever knowing the books or ideologies of atheism. All I knew was science and Islam. In the end, I realised there were many instances when I did not believe but was 
put back into the system by fear, societal norms, family heritage and the pressure to go with the crowd. This is my story.

I was born in the mid 1980s, in the state of Kano in Northern Nigeria. Born to a family of scholars, I trace my lineage to the disciples of Usman dan Fodio, the founder of the Sokoto Caliphate. The dan Fodio Empire conquered and ruled a big chunk of West Africa. Lasting from 1804 to 1903, it enslaved, converted and subjugated diverse tribes into its fold. This included even traditionally Muslim city-states like Kano, Zaria and Bauchi that had been Muslim for centuries. Their faith was not considered pure enough. Consequently, they were attacked and conquered. Arriving British colonialists toppled the empire in 1903.

The only difference between the method of the Caliphate and that of today's Jama'atu Ahlis Sunnah Lida'awati wal Jihad (JAS), commonly known as Boko Haram, is time-lapse. Modernity forced the religion to adapt to a secular constitution. Modern education has given people the impression of freedom. The new name for jihadism is now terrorism. It is why JAS kills Muslims. Their faith is not strong enough; it is diluted by secular, ungodly westernisation, instead of the sharia system Muhammad recommended through allegiance to a line of Caliphs (not Sultans).

The primary school I attended was a Muslim-only school, one of many funded by Saudi Arabia under the Daurah-Islamic Foundation. So was my secondary school: a Muslim-only private school. The area I grew up in Kano is overwhelmingly Muslim. Subsequently, I had the smallest amount of 
contact with non-Muslims or secularism. All I knew was my religion and I was taught that Islam is perfect everyday. At the same time, I understood science, which my school taught with the caveat that it is only true when in agreement with doctrine. Science thrilled me and still does. Growing up, I read more of it than required in the curricula through texts I could find at home. You will notice how easily this aided my journey in the final lapse when my mind was conscious and adult.

During the First Gulf War, our teachers told us how Saddam Hussein was fighting the infidels and winning. I could remember the time we were given extra lessons on jihad and taught to shoot bows and arrows. I was 9. We were told we should be ready for the coming fight and that it was inevitable. The purpose of teaching us science and sports was to learn 'their evil ways, and use it against them'. For some reason however, many, like myself, thought Islam agrees with science, save the 'lies of evolution'.

In 2001, when at 16 and just finishing secondary school, the north of Nigeria was celebrating the September $11^{\text {th }}$ attacks and bin Laden's al Qaeda. I went to the market and selected the best picture of bin Laden in a fighter jet. Now I know it was altered using PhotoShop: the original picture was of a French fighter jet. I brought a big poster, and pasted it at our front yard where friends gathered to listen to the BBC Hausa news and digest if the war with America and Israel was succeeding. We were told it was foretold in the Quran (Q9: 11). This is the poison we were fed. Bin 
Laden's pictures flooded northern Nigeria. They still do in some parts. It is ironic - but not surprising -that now similar ideology is ravaging the region.

That same moment coincided with my discovery of a radio tape, narrated by an apparent American Muslim convert, purportedly exposing a shadowy group who worship the devil and consp ${ }^{1}$ ire to undermine Islam. He called them The Freemasons, evolved from the Knight Templars. He vilified the West and secular leaders as being members of a cult-like agenda bent on dominating the world and brainwashing us with ungodly practices. He called it the New World Order, quoting Bush Senior. Popular culture still calls them The Illuminati.

I transcribed the tape into a book in my last year at school while I was supposed to be studying for my final exams. By the time I got home, I had transferred it to a computer for further distribution, and later the internet. I made several copies and sent these to many people, including those with government positions. I wanted to see my immediate society be better and thought Islam was the solution. Yes, I've always been an activist, long before my struggle between Almajiri and secularist. I thought I was on the right side of the divide then.

Doubts about my faith had always remained in my mind however. At school, I made sure I read all through the Qur'an to see if it chimed with what I knew to be true. I asked too many questions and got unsatisfactory answers or was warned off with phrases like 'God is too mysterious for your 
feeble brain', 'There are things which you just don't ask', 'Careful, you'll incur Allah's wrath with these questions' and 'Naa, they can't go to the moon, it's all a lie'. I intensified study of the religion to increase my faith and prove my doubts wrong.

My first real contact with other types of Nigerians was in 2003 on remedial studies outside of Kano. This opened my eyes to human beings of other religions who I was conditioned to think of as filthy, impure, and the enemy. The most common insult we use for them is 'arna' meaning pagan, even though they are of the Christian and/ or animist faiths. I noticed they were just normal people with similar hopes and aspirations. I befriended many, reasoned with some, and took part in interfaith debates. I got a Bible and studied it for the debates. Even though they were forbidden from touching the Qur'an, I encouraged them to do so, hoping they may see its glory. I became liberal.

I also secured Islamic debate tapes, especially those of Ahmad Deedat, who headed the South African/ Indian Islamic Propagation Centre, which converted many Christians into Muslims. I admired him so much that I lobbied the state government that a road should be named in his honour. The road leading to the Kano Government House is now Ahmad Deedat Road. I met his son Yusuf Deedat who flew in from Durban to commission the road and he thanked me.

I did not want to go to university near home as this meant my father would impose burdens of religion on me so I changed universities after a 
year. At the relatively secular Ahmadu Bello University in Zaria, I had the freedom to meet more people. I learned so much. I read. I debated. I reasoned. Subsequently I became very secular. I saw how religion divided peoples. I imagined a better world. Even at that time I thought Islam was still true and Muslims are just not being Muslim enough.

This time coincided with violent uprisings ignited by Islamists in the name of the Muslim Students' Society (MSS). One of the conditions under which my father had allowed me to leave university in Kano was that I had to join the MSS. I had done so to ensure his economic support. The turmoil led me to break away from the MSS and form my own secular group with the help of a friend. We named it 'I4E', Islam for Earth. Although the name sounds fanatical, I coined it for us to secure legitimacy among those we wished to secularise and gain the resources we needed such as media equipment and a mosque to hold meetings and public lectures.

We soon became seven people, then more. We failed to get a licence at the federal level. The name was too Islamist so we subsequently changed it to Mannah (Heavenly Food) World. We funded this from our own pockets. Its purpose was to secularise and instil tolerance.

The organisation held lectures and Iftar specials (fasting dinners) and distributed banners, fliers, pamphlets and bulletins. I worked hard but failed to introduce university-wide interfaith dialogues. I blamed the failure on the MSS and outside influences, mostly Sharia revivalism and 
tribalism. We had successes though and things quieted down. Religion took the back seat once again. This was around 2007.

Today, the organisation produces jingles and Hausa movies in the Kannywood industry. Its new name is 'New Qamar Productions' (Qamar means the moon). I am no longer involved though. The co-founders think I'm too radical with the new irreligion I openly profess. I still hope to further its purpose, to translate science documentaries about space, the human body and 'how things are made' and other videos that teach philosophy and reason into Hausa.

By 2007, when I went for Hajj, I prayed fervently for guidance. I knew I was clearly diverting from the path due to my doubts. I made it my priority to re-study the religion, re-commit once and for all and to live a life of a pious god-fearing Muslim. I knew my heritage and wished to conserve it. I also nurtured political ambitions, thinking I could offer new ideas and usher in change, but political aspirations in Nigeria all depend on which region or religion one comes from. It is political suicide to be an atheist. Another concern was my hereafter (I still thought there was one). So, I decided to double my efforts, blame the devil for my weakening faith and do what I was supposed to do: study. By then, I was lagging behind academically. My CGPA was strong but without the distraction I would have done far better.

As the years passed, continuous study and posing question to scholars and hearing their answers convinced me that the problem is really Islam. I 
came to realise that its message is tainted. By 2009, I became agnostic. Please note that I just found out these terms in the past year. All I knew back then was my level of faith was decreasing. I reasoned with likeminded people but kept things private, while being openly secular. By then, I had freed myself to think beyond the boundaries set uncrossable by religion, effectively a freethinker.

This went on for years. I realised that most of the answers I sought could not be found, that humanism and social justice cannot be achieved, with religion in our midst, especially the Islam and Christianity inherent in the country. The nature of my writing changed, covertly passing on ideas of secularism, with religion taking the backseat, and having a focus on exposing social injustice that hinders society.

My family noticed the changes and chose to victimise and threaten me over them. I told them I was a rebel now. They did not understand it. They thought it was either the devil or a demon. Any blasphemy is translatable as mental illness. They just could not wrap their heads around the thought that religion, their religion, could be wrong.

The irony is, they have had a better level and quality of education than me. Some lived for years in the UK and only became more bigoted while there. I would say Western governments have failed woefully for allowing unreason to infest the minds of the young. My family thought sanctions, economically, would deter me. I lost many privileges over the years, but freedom surely costs. By now, I know its worth. 
By 2012 , terrorism had hit home and hit hard. A Sept $11^{\text {th }}$ and $7-11$ scenario ravaged my country. Ironically, the same people now pray the US sends over drones or boots on the ground to finish off the terrorists. Some have deluded themselves, thinking the $\mathrm{CIA}$ is funding and aiding the terrorists or even saying it is not Muslims but US operatives or any local tribe they happen to hate. JAS rose from isolated incidents to a regional menace, birthed much like the Taliban in a madrassa system of education and lacking any modern knowledge of the world.

I knew it was a recipe for trouble. Many militant groups had emerged before, but they were primitive in their weaponry and easily crushed - but not this one. The Maitatsine uprising in the early 1980s in Kano for example saw over 10,000 killed in a few months before it was quelled.

Efforts by militant Christians to fan the flames made things worse and further proved a major setback in having people look closely at the religion. The circle of friends I tried to reason with were those with whom I had attended school; the educated, the elite and the leaders of the future. Our debates were mostly private and in person. Some were on BBM and WhatsApp groups and, later, on Facebook. By then I felt more like an atheist but I just was not confident to name myself as such. I was actually afraid of the term.

It was Twitter that catapulted me to realise I had been an atheist all along. All the memes and statements circulating made sense. It was as if I was the one writing them. Anything I would see, I would say, 'Wow! I 
thought of this too!' The time I devoted to learn and reason were all because my brain inherently refused to register fallacies. I understood evolution, and realised why it posed a threat to dogmatic faiths. I do not hate people. I love those I know and have compassion for those I don't, especially the downtrodden. I abhorred terror and all violent extremism. I realised this is humanism.

I calculated the risks but went ahead anyway. I saw urgency to the dangerously escalating situation in Nigeria. I saw us sinking. I realised that if I could tell them who I am and what I believe, doubts may set in, and they may at least go secular, saving the next generation, before we become another Somalia or Afghanistan.

I started subtle debates with close friends, criticising society and religion. Many thought and said it was only 'a phase'. Others said I was becoming a Jew (by Jew they mean Westernised). Friends that had earlier in life trusted my judgment, intuition and analysis now feared what I might say. I reasoned with them so well they feared they may 'lose their faith' and become the 'arna' they were supposed to hate. Many took off. After all, we were all radicalised via the same process. The few that did break free from religion however, wanted to keep things private.

With every terror attack, I become more vocal. That was when the debates and writings became more critical. What finally made me come out as atheist was a video of a beheading of a female Christian back in 2013 
by boys around my age, speaking my language. It hit me that the time for silence is over. Either someone speaks out or we all sink.

I then told people bluntly, including my mother. She was so scared for me that she told my dad. Instead of debating me or asking how I came to that conclusion, he wanted me to see a psychiatric doctor. I finally agreed, giving the condition that the doctor has to be a non-Muslim, which they refused. Finally the pressure mounted and I succumbed. It was November 2013. I was lucky the doctor was secular. He listened to all they had to say. He said this was not a psychiatric problem and that they could only preach to me or pray for me. My father was very unhappy with him and sought another doctor.

By June 2014, they had pre-planned with another doctor without my knowledge. During the very first visit we made, with all the members of the family, the doctor told me I needed a god, and that even in Japan they have a god. He said atheists were all mentally disturbed, that denying the history of Adam and Eve was delusional. They (the doctor, my father and my senior brother) mentioned a story about one Al-Ghazali, an Islamic scholar who questioned Allah, went crazy, repented, and got better.

Being the most senior consultant in the hospital, the doctor said his decision was final. He prescribed a bed for me. I quietly went home as they went to pay for the bed. I started planning to move out of the house. That was when they took me by force. They beat me up, wrestled me and sedated me. They said they would have to kill me if I do not comply. When my story came out in the media, the hospital management cancelled the 
doctor's prescription and assigned me a new doctor. I was re-diagnosed sane but kept in protective custody under State Security. I was told the city and region was demanding for my head as if we are in 14th century Europe. I was appointed a lawyer and a legal process was started. My father sent delegations to plead with me to drop the case. I said he had to apologise in person, not punish those who helped me and return my property. Those terms were long broken, and I decided to seek justice in the future.

The response to my hospitalisation not only saved my life but it encouraged people to question. A number of atheists, especially in Islamic communities in Northern Nigeria, are now confident. They are coming out the closet or reaching out to contribute with ideas or advice for the project of secularising our peoples and winding down the indoctrination of dogma imported from the Middle East which has been ravaging our lands. I hope I have inspired people to have the courage to think and not fear knowledge or something 'new'. It's important to note that ex-Christians in Nigeria have risen too, long before this, vocal and confident.

I wish and plan for a society saturated with tolerance, peace, accommodation, reason and harmony. It may not be today that we solve all our problems but we need to see religious indoctrination as the viral programme it is. 
Islam has some 1.5 billion people. Many of us are victims and prisoners of conscience, struggling for reason and freedom from our religion.

Remove the apostasy laws, the imaginary hellfire and see if our number reaches a billion.

Mubarak Bala is a humanist, an ex-Muslim and an atheist. He is on Twitter @mubarakbala

To cite this article:

Bala, M. (2016) My Journey From Islamist to Free Thinker. Feminist Dissent. (1), 119-130. Retrieved from:

http://journals.warwick.ac.uk/index.php/feministdissent/article/view/19 